\begin{tabular}{|c|c|c|}
\hline \multirow{3}{*}{$\begin{array}{r}\text { Case Reports in } \\
\text { Gastroenterology }\end{array}$} & \multirow{2}{*}{\multicolumn{2}{|c|}{ Case Rep Gastroenterol 2016;10:174-180 }} \\
\hline & & \\
\hline & $\begin{array}{l}\text { 10.1159/000445867 } \\
\text { Puotisned oninne: Tvlay 2, } 2016\end{array}$ & $\begin{array}{l}\text { ( } 2016 \text { The Author(s) } \\
\text { Published by S. Karger AG, Basel } \\
1662-0631 / 16 / 0101-0174 \$ 39.50 / 0 \\
\text { www.karger.com/crg }\end{array}$ \\
\hline
\end{tabular}

\title{
Pancreatic Acinar Cell Carcinoma
}

\author{
Dominique Béchade Marie Desjardin Emma Salmon \\ Grégoire Désolneux Yves Bécouarn Serge Evrard Marianne Fonck \\ Groupe Digestif, Institut Bergonié, Bordeaux, France
}

\section{Keywords}

Acinar cell carcinoma $\cdot$ Pancreas

\begin{abstract}
Pancreatic acinar cell carcinoma (ACC) is a rare malignant neoplasm that accounts for $1-2 \%$ of all pancreatic neoplasms. Here we report two cases of ACC and describe their clinical features, the therapies used to treat them, and their prognosis. The first patient was a 65 -yearold woman who had an abdominal CT scan for a urinary infection. Fortuitously, a rounded and well-delimited corporeal pancreatic tumor was discovered. An endoscopic ultrasound (EUS)-guided fine needle aspiration revealed an ACC. During the puncture, a hypoechoic cavity appeared inside the lesion, corresponding to a probable necrotic area. Treatment consisted of a distal splenopancreatectomy. The second patient was a 75-year-old man who complained of abdominal pain. An abdominal CT scan showed a cephalic pancreatic lesion and two hepatic metastases. An EUS-guided fine needle aspiration showed a pancreatic ACC. The patient received chemotherapy with gemcitabine plus oxaliplatin (GEMOX regimen), which enabled an objective response after 6 cycles.

(C) 2016 The Author(s)

Published by S. Karger AG, Basel
\end{abstract}

\section{Introduction}

Although acinar cells predominate in the normal pancreas, their malignant transformation is rare, representing $1-2 \%$ of malignant pancreatic tumors [1]. Although considered 
as a single tumor entity, acinar cell carcinomas (ACCs) vary in their morphological and clinicopathological characteristics [2]. ACCs are generally nonsymptomatic but dominated by abdominal pain, while jaundice is less frequent than in adenocarcinomas [3]. One of the forms - lipase hypersecretion syndrome - is characterized by fever, arthralgia, rash, nodular panniculitis (Weber-Christian syndrome), and hypereosinophilia [4]. Over 50\% of cases are known to present hyperlipasemia [1]. Most radiological studies [3-8] describe large lesions, often ovoid with sharp boundaries, rarely causing retrodilation of the bile duct and/or the pancreatic duct [8]. Magnetic resonance imaging scans of ACCs often show less dense intralesional areas that may correspond to hypovascularized neoplastic tissue or necrotic portions [3].

Here we report two cases of ACC that show certain clinical features of these tumors and discuss the therapeutic and prognostic aspects of the two cases.

\section{Case Reports}

A 65-year-old female patient with a history of breast neoplasia had an abdominopelvic CT scan for a urinary infection. Unexpectedly, a rounded and well-delimited pancreatic tumor was discovered on the CT scan (fig. 1). On endoscopic ultrasound (EUS), this homogeneous and hypoechoic lesion was separated from the liver and stomach by a hyperechoic border (fig. 2). We performed EUS fine needle aspiration (EUS-FNA) with a 19-gauge ProCore needle (ECHO-HD-19-C; Cook Medical). During the puncture, a hypoechoic cavity appeared inside the lesion (fig. 3). A vessel, seen by Doppler analysis, joined the cavity and the peripheral border of the mass, which disappeared at the end of the procedure. Histological examination revealed acinar proliferation with cylindrocubic patterns, eosinophilic cytoplasm, and a regular nucleus without mitosis. Immunohistochemically, the tumor cells were positive for cytokeratin AE1/AE3, epithelial membrane antigen, and BCL10 (fig. 4A), and negative for CK7 (fig. 4B), CK20, chromogranin, and synaptophysin, consistent with ACC. The patient complained of epigastric pain the day after EUS-FNA, and a CT showed necrotic lesions inside the tumor. The pain disappeared spontaneously. Treatment consisted of a distal splenopancreatectomy 2 weeks later.

Another patient, aged 75 years with no major history, was hospitalized for abdominal pain. A scan showed an 80-mm cephalic lesion in the pancreas composed of tissue and cysts, which was responsible for a retrodilation of the main pancreatic duct (fig. 5). There were two hepatic metastatic lesions, measuring $12 \mathrm{~mm}$ at segment VII and $23 \mathrm{~mm}$ at the junction of segments V and VIII. ACC was diagnosed upon EUS-FNA. Chemotherapeutic treatment consisting of gemcitabine $\left(1,000 \mathrm{mg} / \mathrm{m}^{2}\right)$ and oxaliplatin $\left(130 \mathrm{mg} / \mathrm{m}^{2}\right)$ every 2 weeks (GEMOX) was administered. Following 6 cycles of chemotherapy, the primary lesion on the pancreatic head had disappeared (fig. 6) and a decrease in size of the liver metastases was observed. Subsequent therapeutic management consisted of radiation therapy for the primary lesion and radiofrequency treatment for the two liver metastases. Six months later, the patient was asymptomatic with normal follow-up scans.

\section{Discussion}

The two cases we report show characteristics of ACC of the pancreas. These tumors generally occur in the 50- to 70-year age group. ACCs are often discovered rather fortuitous- 
ly during routine examination of abdominal complaints. Most scans of ACC lesions show hypovascularized neoplastic tissue and necrotic areas, as observed in the first case following EUS-FNA puncture [9].

At the pathological level, ACCs can be easily distinguished from ductal pancreatic adenocarcinomas $[2,10]$ as the cells express immunohistochemical markers that are implicated in acinar differentiation (trypsin, chymotrypsin, and BCL10). As in our first case, expression of BCL10 is involved in these tumors [11]. On the other hand, differentiation from neuroendocrine tumors or pancreatoblastomas is rather difficult, especially when genuine mixed forms exist $[12,13]$. Molecular alterations in the APC/ $\beta$-catenin pathway including APC-inactivating mutations and CTNNB1-activating mutations are very common [12, 13]. Furthermore, BRCA2 mutations are also associated with ACCs [14].

Surgery remains the best treatment for localized tumors, as illustrated in our first case. Few data are available regarding the chemosensitivity of metastatic tumors. Various chemotherapy protocols have been reported in several clinical cases, with objective responses described with FOLFOX protocols [15], FOLFIRINOX [16], LV5FU2/gemcitabine [17], weekly paclitaxel, or LV5FU2/cisplatin [18, 19]. To our knowledge, only one study reports, as a secondary observation, a spectacular response with the GEMOX regimen that enabled survival for 14 years [20]. One group of researchers reported the 8-year survival of a patient with metastatic ACC via the study of specific genomic and epigenetic alterations which led to personalized treatment with doxorubicin [21]. The prognosis of ACC of the pancreas appears better than that of ductal adenocarcinomas at all stages; 5-year survival was 17.2 versus $2.8 \%$ for ductal adenocarcinoma at the metastatic stage [22], and in locally advanced, unresectable cases, overall survival was 25 versus 3 months [23].

Pancreatic ACCs are rare tumors with clinical features and prognostics that appear unique to malignant tumors of the pancreas. Therapeutically, besides surgery for resectable tumors, the combination of oxaliplatin-based chemotherapy appears most effective for locally advanced or metastatic forms.

\section{Acknowledgements}

The authors would like to thank Dr. Ravi Nookala of the Institut Bergonié for medical writing services.

\section{Statement of Ethics}

This study did not require ethics approval.

\section{Disclosure Statement}

The authors have no conflicts of interest or financial ties to disclose.

\section{References}

1 Klimstra DS: Nonductal neoplasms of the pancreas. Mod Pathol 2007;20:S94-S112. 
2 La Rosa S, Sessa F, Capella C: Acinar cell carcinoma of the pancreas: overview of clinicopathologic features and insights into molecular pathology. Front Med (Lausanne) 2015;2:41.

-3 Tian L, Lv XF, Dong J, Zhou J, Zhang Y, Xi SY, et al: Clinical features and CT/MRI findings of pancreatic acinar cell carcinoma. Int J Clin Exp Med 2015;8:14846-14854.

4 Butturini G, Pisano M, Scarpa A, D’Onofrio M, Auriemma A, Bassi C: Aggressive approach to acinar cell carcinoma of the pancreas: a single-institution experience and a literature review. Langenbecks Arch Surg 2011;396:363-369.

-5 Raman SP, Hruban RH, Cameron JL, Wolfgang CL, Kawamoto S, Fishman EK: Acinar cell carcinoma of the pancreas: computed tomography features - a study of 15 patients. Abdom Imaging 2013;38:137143.

-6 Tatli S, Mortele KJ, Levy AD, Glickman JN, Ros PR, Banks PA, et al: CT and MRI features of pure acinar cell carcinoma of the pancreas in adults. AJR Am J Roentgenol 2005;184:511-519.

7 Chiou YY, Chiang JH, Hwang JI, Yen CH, Tsay SH, Chang CY: Acinar cell carcinoma of the pancreas: clinical and computed tomography manifestations. J Comput Assist Tomogr 2004;28:180-186.

8 Hsu MY, Pan KT, Chu SY, Hung CF, Wu RC, Tseng JH: CT and MRI features of acinar cell carcinoma of the pancreas with pathological correlations. Clin Radiol 2010;65:223-229.

$\checkmark 9$ Kanno A, Masamune A, Hamada S, Kikuta K, Kume K, Hirota M, et al: Sudden disappearance of the blood flow in a case of pancreatic acinar cell carcinoma. Intern Med 2014;53:2589-2593.

10 Wood LD, Klimstra DS: Pathology and genetics of pancreatic neoplasms with acinar differentiation. Semin Diagn Pathol 2014;31:491-497.

11 Hosoda W, Sasaki E, Murakami Y, Yamao K, Shimizu Y, Yatabe Y: BCL10 as a useful marker for pancreatic acinar cell carcinoma, especially using endoscopic ultrasound cytology specimens. Pathol Int 2013;63:176-182.

12 Stelow EB, Shaco-Levy R, Bao F, Garcia J, Klimstra DS: Pancreatic acinar cell carcinomas with prominent ductal differentiation: mixed acinar ductal carcinoma and mixed acinar endocrine ductal carcinoma. Am J Surg Pathol 2010;34:510-518.

13 Liu Z, Dong C, Wang C, Liu Q, Sun D, Wang L: Mixed acinar-endocrine carcinoma of pancreas: a case report and brief review of the literature. Onco Targets Ther 2015;8:1633-1642.

14 Furukawa T, Sakamoto H, Takeuchi S, Ameri M, Kuboki Y, Yamamoto T, et al: Whole exome sequencing reveals recurrent mutations in BRCA2 and FAT genes in acinar cell carcinomas of the pancreas. Sci Rep 2015;5:8829.

15 Simon M, Bioulac-Sage P, Trillaud H, Blanc JF: FOLFOX regimen in pancreatic acinar cell carcinoma: case report and review of the literature. Acta Oncol 2012;51:403-405.

$>16$ Schempf U, Sipos B, König C, Malek NP, Bitzer M, Plentz RR: FOLFIRINOX as first-line treatment for unresectable acinar cell carcinoma of the pancreas: a case report. Z Gastroenterol 2014;52:200-203.

17 Sorscher SM: Metastatic acinar cell carcinoma of the pancreas responding to gemcitabine, 5fluorouracil and leucovorin therapy: a case report. Eur J Cancer Care (Engl) 2009;18:318-319.

18 Distler M, Rückert F, Dittert DD, Stroszczynski C, Dobrowolski F, Kersting S, et al: Curative resection of a primarily unresectable acinar cell carcinoma of the pancreas after chemotherapy. World J Surg Oncol 2009;7:22.

19 Riechelmann RP, Hoff PM, Moron RA, da Câmera Lopes LH, Buzaid AC: Acinar cell carcinoma of the pancreas. Int J Gastrointest Cancer 2003;34:67-72.

20 Ploquin A, Baldini C, Vuagnat P, Makhloufi S, Desauw C, Hebbar M: Prolonged survival in a patient with a pancreatic acinar cell carcinoma. Case Rep Oncol 2015;8:447-450.

-21 Armstrong MD, Von Hoff D, Barber B, Marlow LA, von Roemeling C, Cooper SJ, et al: An effective personalized approach to a rare tumor: prolonged survival in metastatic pancreatic acinar cell carcinoma based on genetic analysis and cell line development. J Cancer 2011;2:142-152.

-22 Schmidt CM, Matos JM, Bentrem DJ, Talamonti MS, Lillemoe KD, Bilimoria KY: Acinar cell carcinoma of the pancreas in the United States: prognostic factors and comparison to ductal adenocarcinoma. J Gastrointest Surg 2008;12:2078-2086.

23 Cananzi FCM, Jayanth A, Lorenzi B, Belgaumkar A, Mochlinski K, Sharma A, et al: 'Chronic' metastatic pancreatic acinar cell carcinoma. Pancreatology 2013;13:549-552. 


\begin{tabular}{|c|c|c|}
\hline & \multirow{2}{*}{\multicolumn{2}{|c|}{ Case Rep Gastroenterol 2016;10:174-180 }} \\
\hline \multirow{2}{*}{$\begin{array}{l}\text { Case Reports in } \\
\text { Gastroenterology }\end{array}$} & & \\
\hline & $10.1159 / 000445867$ & $\begin{array}{l}\text { ( ) } 2016 \text { The Author(s). Published by S. Karger AG, Basel } \\
\text { www.karger.com/crg }\end{array}$ \\
\hline
\end{tabular}

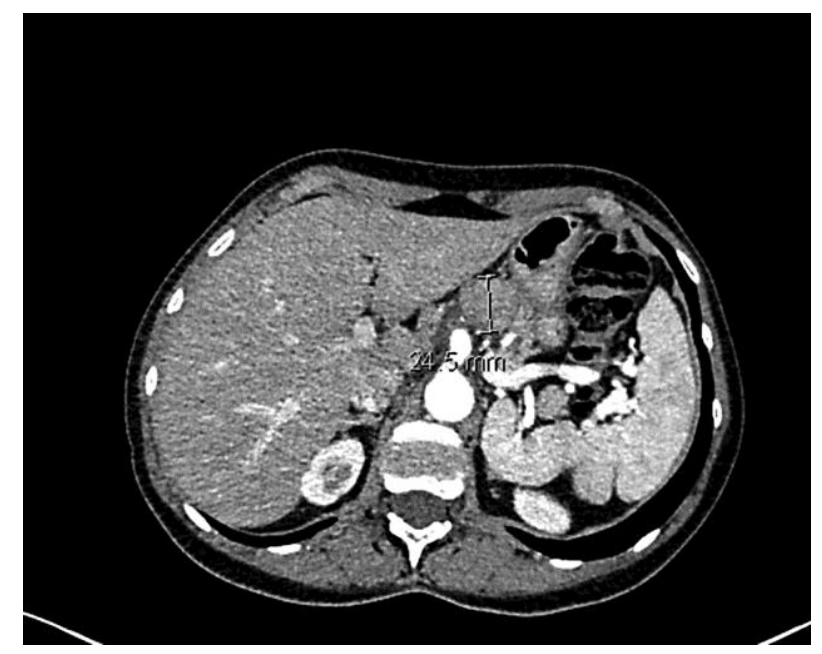

Fig. 1. Abdominal CT. Pancreatic tumor mass compared to the celiac region.

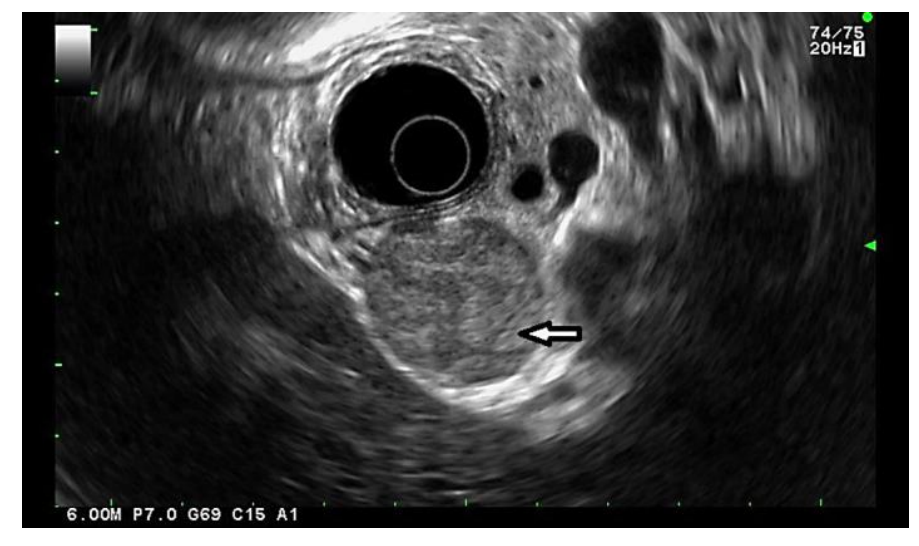

Fig. 2. EUS. Rounded lesion with clear borders (arrow).

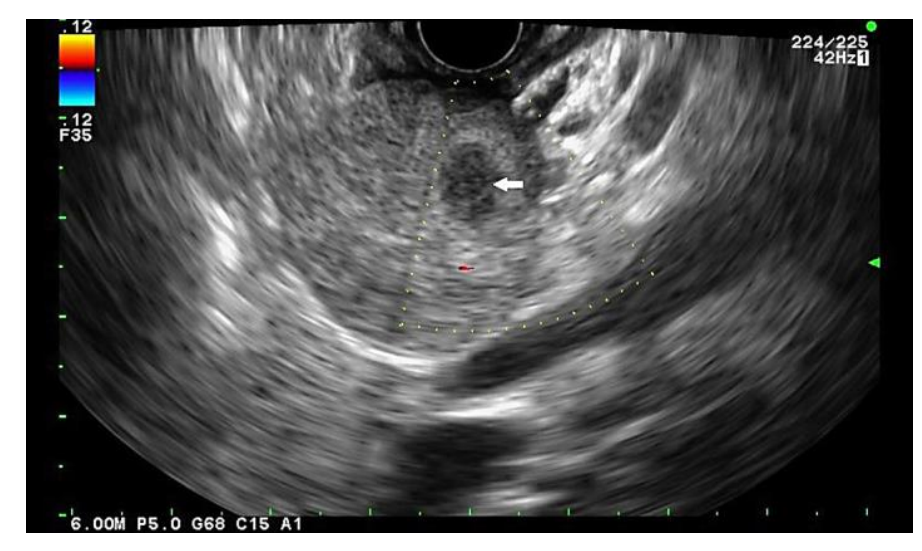

Fig. 3. Appearance of a hypoechoic cavity within the lesion during puncture using EUS (arrow). 


\begin{tabular}{ll|l} 
Case Reports in & \multicolumn{2}{c}{ Case Rep Gastroenterol 2016;10:174-180 } \\
\cline { 2 - 3 } Gastroenterology & $\begin{array}{l}\text { 10.1159/000445867 } 2016 \text { The Author(s). Published by S. Karger AG, Basel } \\
\text { www.karger.com/crg }\end{array}$ \\
\cline { 2 - 3 } & & Béchade et al: Pancreatic Acinar Cell Carcinoma
\end{tabular}
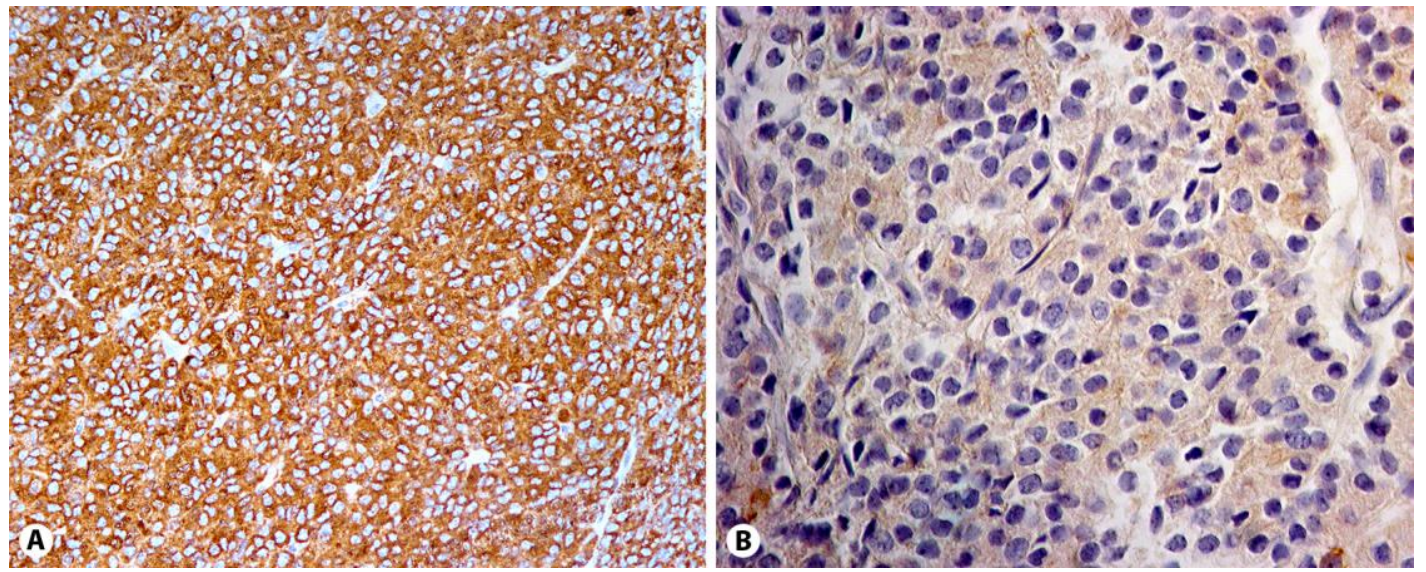

Fig. 4. A Positive staining with BCL10. $\times 200$. B Negative staining with CK7. There is a cytoplasmic background without membrane staining. $\times 100$.

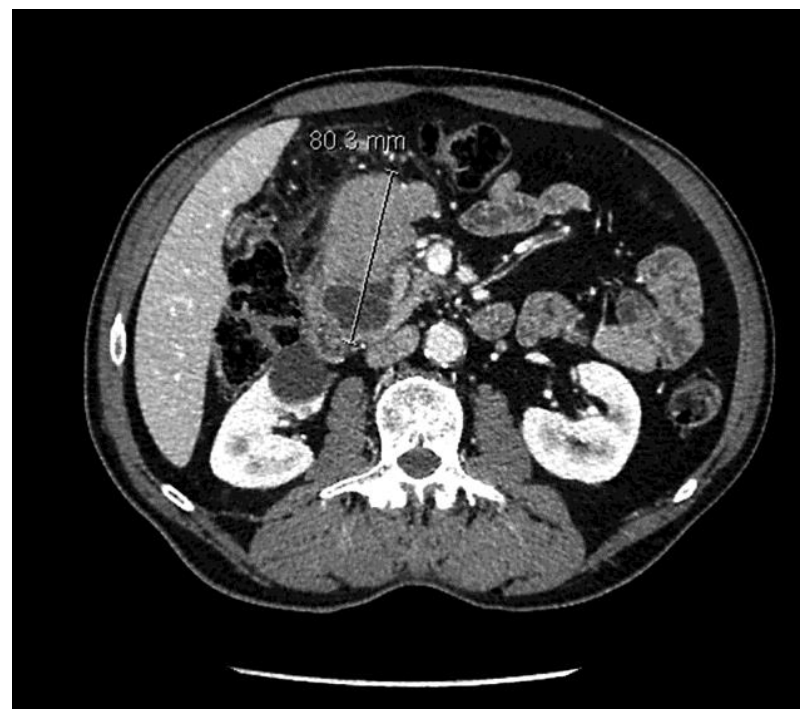

Fig. 5. Abdominal CT. Bulky tumor mass in the pancreatic head measuring $80.3 \mathrm{~mm}$ (long axis). 


\begin{tabular}{|c|c|c|}
\hline & \multirow{2}{*}{\multicolumn{2}{|c|}{ Case Rep Gastroenterol 2016;10:174-180 }} \\
\hline \multirow{2}{*}{$\begin{array}{l}\text { Case Reports in } \\
\text { Gastroenterology }\end{array}$} & & \\
\hline & $10.1159 / 000445867$ & $\begin{array}{l}\text { ( } 2016 \text { The Author(s). Published by S. Karger AG, Basel } \\
\text { www.karger.com/crg }\end{array}$ \\
\hline
\end{tabular}

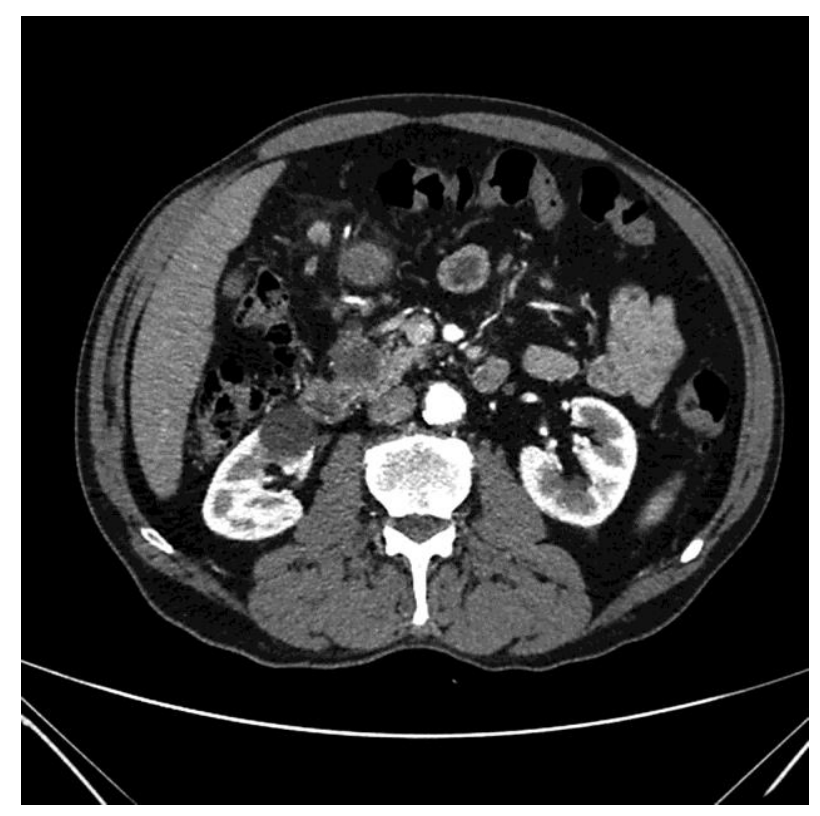

Fig. 6. Therapeutic response obtained after 6 cycles of GEMOX treatment. 